\title{
Glycogen synthase kinase-3 $\beta$ regulates tumor necrosis factor-related apoptosis inducing ligand (TRAIL)-induced apoptosis via the NF-кB pathway in hepatocellular carcinoma
}

\author{
KAI FU ${ }^{1 *}$, HUAZHENG PAN ${ }^{2 *}$, SHIHAI LIU ${ }^{3}$, JING LV $^{1}$, ZHAOJUN WAN ${ }^{1}$, JIAO LI ${ }^{1}$, \\ QING SUN ${ }^{1}$ and JUN LIANG ${ }^{1}$ \\ ${ }^{1}$ Department of Oncology; ${ }^{2}$ Clinical Laboratory; ${ }^{3}$ Central Laboratory, \\ The Affiliated Hospital of Qingdao University, Qingdao, Shandong 266003, P.R. China
}

Received November 15, 2014; Accepted June 25, 2015

DOI: $10.3892 / \mathrm{ol} .2015 .3803$

\begin{abstract}
Tumor necrosis factor (TNF)-related apoptosis-inducing ligand (TRAIL) is known for its ability to selectively induce apoptosis in malignant cells. However, human hepatocellular carcinoma (HCC) cells display resistance to TRAIL-induced cell death. The present study investigated whether TRAIL-induced apoptosis in HCC cells was enhanced by the administration of an inhibitor of glycogen synthase kinase-3 $\beta$ (GSK-3 $\beta$ ) or by short hairpin RNA-mediated inhibition of GSK-3 $\beta$. The results of the current study demonstrated that inhibition of GSK- $3 \beta$ significantly impairs the expression of the nuclear factor- $\mathrm{\kappa B}$ (NF- $\mathrm{\kappa B}$ ) target genes $\mathrm{Bcl}-\mathrm{xL}$ and clAP2 in HCC cells $(\mathrm{P}<0.05)$. This indicates that GSK-3 $\beta$ may regulate NF- $\kappa \mathrm{B}$ target genes involved in cell survival. Furthermore, knockdown of Bcl-xL significantly enhanced the sensitizing effect of GSK-3 $\beta$ inhibitor on TRAIL-induced apoptosis $(\mathrm{P}<0.05)$. Overall, the present study provides a rationale for further exploration of GSK- $3 \beta$ inhibition combined with TRAIL as a novel treatment for HCC.
\end{abstract}

\section{Introduction}

Hepatocellular carcinoma (HCC) is one of the most common types of malignant primary liver cancer and is the third leading cause of cancer-related mortality worldwide (1). Although surgery remains the preferred therapeutic strategy for HCC, tumor size, hepatic functional reserve and/or portal

Correspondence to: Professor Jun Liang, Department of Oncology, The Affiliated Hospital of Qingdao University, 16 Jiangsu Road, Qingdao, Shandong 266003, P.R. China

E-mail: liangjun1959@aliyun.com

"Contributed equally

Key words: glycogen synthase kinase-3 $\beta$, apoptosis, tumor necrosis factor-related apoptosis-inducing ligand, nuclear factor- $\kappa \mathrm{B}$, hepatocellular carcinoma hypertension may all limit the extent of surgical resection (2). Chemotherapy and internal radiation therapy are also used to treat liver cancer (3), however, both can lead to the damage of tissues and organs unaffected by cancer. The prognosis of HCC is poor due to the development of resistance to current chemotherapy regimens through the downregulation of various signaling pathways; in particular, those that control cell proliferation and survival, such as nuclear factor $\mathrm{\kappa B}$ (NF-kB) (4). Thus, the development of novel, effective therapeutic strategies for $\mathrm{HCC}$ are required to improve the prognosis of this disease.

Tumor necrosis factor (TNF)-related apoptosis-inducing ligand (TRAIL) belongs to the TNF superfamily (5) and possesses a number of anti-cancer properties $(6,7)$. For example, TRAIL can induce apoptosis in tumor cells by binding to the plasma membrane death receptors (DRs) TRAIL-R1 (DR4) and TRAIL-R2 (DR5) (8). Therefore, TRAIL is a potential candidate for cancer treatment (9). However, HCC cells are intrinsically resistant to TRAIL-induced cell death (10). This resistance to TRAIL is a major clinical challenge that leads to failure of treatment, poor prognosis and reduced survival of patients with HCC (10). Previous studies have demonstrated that TRAIL can activate the NF- $\kappa B$ signaling pathway, which activates genes that encode various key anti-apoptotic proteins, such as B-cell lymphoma-extra large (Bcl-xL) and inhibitor of apoptosis proteins (IAPs). These proteins contribute to TRAIL resistance $(10,11)$. Thus, overcoming NF- $\kappa \mathrm{B}$-associated survival signals may enhance the antitumor effect of TRAIL in HCC cells.

Glycogen synthase kinase-3 (GSK-3) is a multifunctional serine/threonine protein kinase that participates in numerous cellular processes, including protein synthesis, glycogen metabolism, mitosis and apoptosis. Additionally, GSK-3 is involved in various signaling pathways, such as the Wnt $/ \beta$-catenin signaling pathway (12). Two major GSK-3 isoforms (GSK- $\alpha$ and GSK-3 $\beta$ ) have been identified in mammals; they are encoded by distinct genes and perform different functions $(13,14)$. Mice with a homozygous deletion of the GSK-3 $\beta$ gene experience massive hepatocyte apoptosis during embryogenesis, leading to premature death (15). Furthermore, previous studies have demonstrated that GSK-3 $\beta$ 
is important in cell survival through its ability to regulate the $\mathrm{NF}-\kappa \mathrm{B}$ signaling pathway in hepatocytes (16).

In consideration of the role of $\mathrm{NF}-\kappa \mathrm{B}$ target genes on TRAIL-induced apoptosis, the present study aims to evaluate the effect of GSK-3 $\beta$ on TRAIL-induced cell death and examine the mechanism by which GSK-3 $\beta$ inhibition sensitizes HCC cells to TRAIL-induced apoptosis.

\section{Materials and methods}

Cell culture. HL7702, SMMC7721, HuH-7, HuH-6 and HepG2 Human HCC cell lines were purchased from the American Type Culture Collection (Manassas, VA, USA). Cells were grown at $37^{\circ} \mathrm{C}$ in a $5 \% \mathrm{CO}_{2}$ humidified atmosphere, and cultured as a monolayer in RPMI-1640 medium (HyClone, Logan, UT, USA) supplemented with $100 \mathrm{U} / \mathrm{ml}$ penicillin, $100 \mu \mathrm{g} / \mathrm{ml}$ streptomycin, $2 \mathrm{mmol} / \mathrm{l}$ glutamine and $10 \%$ fetal bovine serum. HCC cell growth was observed and recorded regularly.

Reagents and antibodies. Annexin V-R-phycoerythrin (PE) and propidium iodide (PI) were purchased from Invitrogen Life Technologies (Carlsbad, CA, USA), and GSK-3 $\beta$ inhibitor (SB216763) was purchased from Sigma-Aldrich (St. Louis, MO, USA). Rabbit anti-human monoclonal antibodies raised against GSK-3 $\beta$ (cat no. 12456; 1:1,000), TRAIL (cat. no. 3219; 1:500), GAPDH (cat. no. 2118; 1:2,000) and $\beta$-catenin (cat no. 8480; 1:1,000) were purchased from Cell Signaling Technology, Inc. (Danvers, MA, USA). Rabbit anti-human monoclonal antibodies raised against Bcl-xL (cat no. ab2568; 1:1,000) and cellular IAP2 (cIAP2; cat no. ab32059; 1:1,000) were purchased from Abcam (Cambridge, UK). Recombinant Ad5.TRAIL, short hairpin (sh) GSK-3 $\beta$, shBcl-xL and short shcIAP2 constructs were obtained from the Central Laboratory, The Affiliated Hospital, Qingdao University (Qingdao, China).

GSK-3 $\beta$ inhibitor (SB216763). SB216763 is potent and selective ATP-competitive GSK-3 inhibitor. It is equally effective at inhibiting human GSK-3 $\alpha$ and GSK-3 $\beta$ (17). HepG2 and HuH-7 cells ( $1 \times 10^{5}$ cells/well) were seeded in 96-well plates and incubated with Dulbecco's modified Eagle's medium (DMEM; HyClone) for $24 \mathrm{~h}$. The cells were then pretreated with $10 \mu \mathrm{M}$ SB216763 in 10\% fetal bovine serum and $1 \mu \mathrm{mol} / 1$ DMEM for $24 \mathrm{~h}$ at $37^{\circ} \mathrm{C}$ in an atmosphere of $5 \% \mathrm{CO}_{2}$.

Construction of the pGenesil-GSK-3 $\beta$ short interfering (si)RNA. Three pairs of shRNAs were used for screening to obtain the most effective downregulation of the gene fragment. Non-targeting siRNA (Wuhan Genesil Biotechnology Co., Ltd., Wuhan, China) was used as the negative control. Using siRNA design software (http://sirna.wi.mit.edu/), the following three coding regions corresponding to the target GSK-3 $\beta$ were selected as siRNA target sequences in the enzyme site of the GFP-tagged pGenesil-1 vector (pGenesil-1-GFP; Wuhan Genesil Biotechnology Co., Ltd.): 5'-ACTGGTCGCCAT-CAAGAAA-3' (471-489 bp); 5'-GAAAGCTA-GATCACTGTAA-3' (536-554 bp); and 5'-GCCACT-GATTATACCTCTA-3' (922-940 bp). In addition, an unrelated sequence was designed for the negative control: 5'-TTCTCCGAACGTCTCACGT-3'. Two oligonucleotides encoding the target shRNA and its complementary sequence were annealed and ligated, and the pGenesil-1-GFP vector was cleaved by BamHI and HindIII (Wuhan Genesil Biotechnology Co., Ltd.). Then the products of both reactions were recovered and purified. The shRNA oligonucleotide fragment and the pGenesil-1-GFP vector were ligated using T4 ligase (Takara Bio, Inc., Shiga, Japan), and the recombinant plasmids were termed pGenesil-GFP GSK-3 $\beta$ shRNA $1-3$. Next, pGenesil-GFP-GSK-3 $\beta$ shRNAs 1-3 $(8 \mu \mathrm{g})$ were transfected into HepG2 cells, respectively, using $20 \mu 1$ Lipofectamine 2000 reagent (Invitrogen Life Technologies), according to the manufacturer's instructions. The most effective shRNA expression cassette, $\mathrm{p}$-Genesil-GSK-3 $\beta$ shRNA 1, was selected as described previously (18), and excised from the pGenesil-1-GFP vector by Bam HI and $M l u \mathrm{I}$, and ligated into a pLV-mCMV-ZsGreen-PGK-puro shuttle vector (Wuhan Genesil Biotechnology Co., Ltd.), termed pLV-GSK-3 $\beta$ shRNA. Plasmids were purified with a MaxPrep kit (Wuhan Genesil Biotechnology Co., Ltd.) and successful ligations were verified by sequencing (Sangon Biotech Co., Ltd., Shanghai, China). Recombinant lentiviral vectors were produced by co-transfecting HepG2 cells with the lentiviral expression plasmid and packaging plasmids using the calcium phosphate method. Briefly, $8 \mu \mathrm{g}$ shRNA plasmid DNA, $5 \mu \mathrm{g}$ lentiviral helper-1, $6 \mu \mathrm{g}$ lentiviral helper-2 plasmids were mixed with sterile $\mathrm{ddH}_{2} \mathrm{O}$ to a final volume of $450 \mu \mathrm{l}$ and mixed with $50 \mu \mathrm{l}$ of $2.5 \mathrm{M} \mathrm{CaCl}_{2}$. Following transfection, infectious media containing shRNA lentiviral vectors was harvested at 48 and $72 \mathrm{~h}$.

Cell viability assay. The effect of shGSK-3 $\beta$ and shRNA on HCC cell viability was measured using the 3-(4,5-dimethylthiazol-2-yl)-2,5-diphenyltetrazolium bromide (MTT) assay. The HepG2 cell line, which is derived from well-differentiated hepatocellular carcinoma, can be grown successfully on a large scale, secretes numerous plasma proteins, and is composed of adherent epithelial-like cells that grow as monolayers and in small aggregates; therefore, these cells were used to investigate cell viability. HepG 2 cells $\left(5 \times 10^{3}\right.$ cells/well) were seeded in 96-well plates in triplicate, and infected with shGSK-3 $\beta$ and negative control shRNA at a multiplicity of infection (MOI) of 10. Control cells were treated with DMEM. After growing for 24,48 and $72 \mathrm{~h}$ at $37^{\circ} \mathrm{C}$ in a $5 \% \mathrm{CO}_{2}$ atmosphere, $20 \mu \mathrm{l}$ of $5 \mathrm{mg} / \mathrm{ml} \mathrm{MTT}$ [in phosphate-buffered saline (PBS)] was added to each well and continually incubated for $4 \mathrm{~h}$ at $37^{\circ} \mathrm{C}$ in a $\mathrm{CO}_{2}$ incubator. The formazan granules obtained from the cells were dissolved in $150 \mu \mathrm{l}$ dimethylsulfoxide for $10 \mathrm{~min}$. Cell viability was measured in terms of the optical density using an enzyme-linked immune detector (Multiskan GO; Thermo Fisher Scientific, Inc., Waltham, MA, USA) at a wavelength of $570 \mathrm{~nm}$. Each cell viability assay was performed in triplicate.

Flow cytometric analysis. HuH-7 cells were treated with $10 \mu \mathrm{M}$ GSK-3 $\beta$ inhibitor, Ad5.TRAIL, shBcl-xL and shcIAP2 alone or in combination at an MOI of 10 for $48 \mathrm{~h}$ at $37^{\circ} \mathrm{C}$ in a $5 \% \mathrm{CO}_{2}$ atmosphere. Adherent and suspended cells were collected, washed in PBS and then suspended in Annexin binding buffer (Immunotech, Marseille, France). Subsequently, cells were stained with Annexin V-PE or PI to distinguish between apoptotic and dead cells. All steps were conducted in accordance with the Annexin binding buffer manufacturer's instructions. Finally, the stained cells were analyzed by flow cytometry using a FC 500 MPL Flow Cytometer (Becton Dickinson, San Jose, CA, USA). 
A

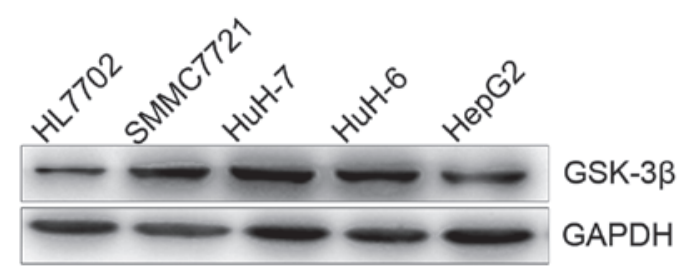

B

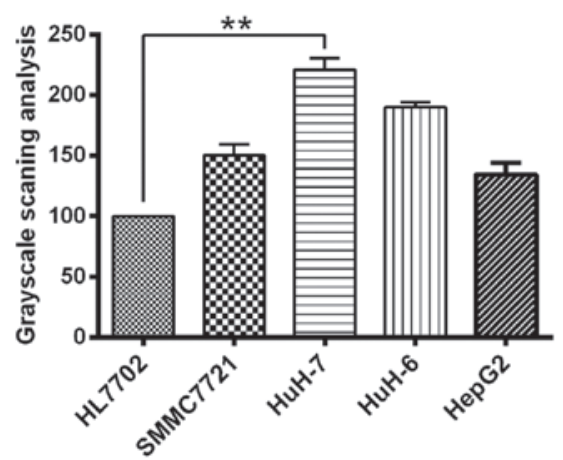

Figure 1. Expression of GSK-3 $\beta$ in five hepatocellular carcinoma cell lines. (A) Western blot analysis of GSK-3 $\beta$ expression. GAPDH served as an internal control. (B) Grayscale scanning analysis revealing that HuH-7 cells express high levels of GSK-3 $\beta$ compared with HL7702 cells. ${ }^{* *} \mathrm{P}<0.05$. GSK-3 $\beta$, glycogen synthase kinase $3 \beta$.

A

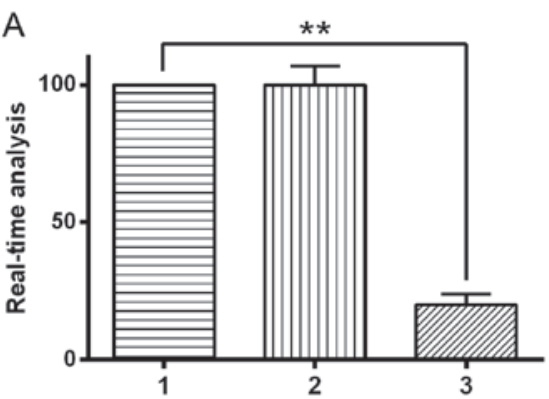

。

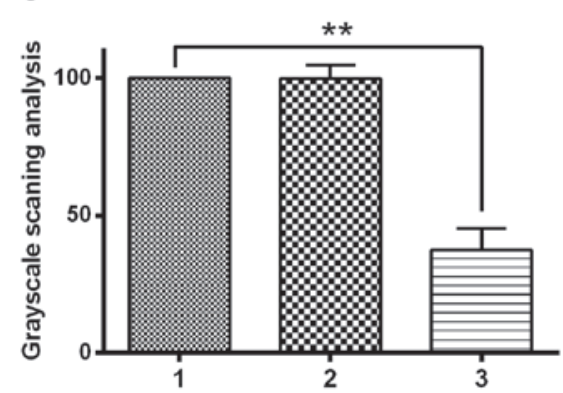

B

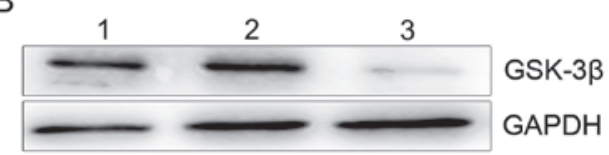

$\mathrm{D}$

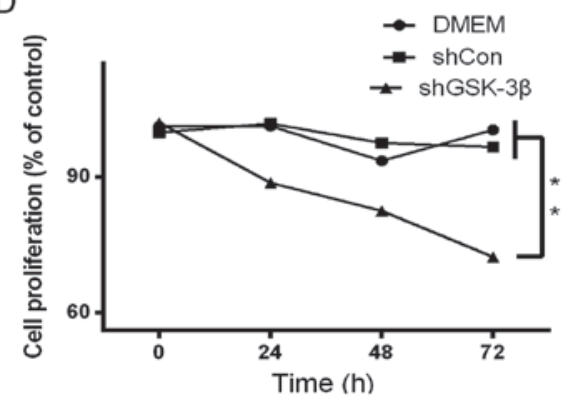

Figure 2. Effect of GSK-3 $\beta$ knockdown by shGSK-3 $\beta$ in HepG2 hepatocellular carcinoma cells. HepG2 cells were transfected with pGenesil vector harboring shRNA targeting GSK-3 $\beta$. Lane 1, shRNA transfected into HepG2 cells; lane 2, blank HepG2 cells; lane 3, shGSK-3 $\beta$ transfected into HepG2 cells. (A) RT-qPCR and (B) western blot analysis of GSK-3 $\beta$ mRNA and protein expression level, respectively. (C) Grayscale scanning analysis revealing that the expression of GSK-3 $\beta$ was reduced in HepG2 cells transfected with shGSK-3 $\beta$. (D) Effect of shGSK-3 $\beta$ on the viability of HepG2 cells. HepG2 cells were treated with shGSK-3 $\beta$ for $72 \mathrm{~h}$ and cell viability was determined by the 3-(4,5-dimethylthiazol-2-yl)-2,5-diphenyltetrazolium bromide assay. ${ }^{* *} \mathrm{P}<0.05$. RT-qPCR, reverse transcription-quantitative polymerase chain reaction; GSK-3 $\beta$, glycogen synthase kinase $3 \beta$; DMEM, Dulbecco's modified Eagle's medium; sh, short hairpin; Con, control.

Western blot analysis. Cell samples were lysed in ice-cold lysis buffer (Beyotime Institute of Biotechnology) with 1\% phenylmethylsulfonyl fluoride for $30 \mathrm{~min}$ and then centrifuged at $10,000 \mathrm{x} \mathrm{g}$ for $20 \mathrm{~min}$ at $4^{\circ} \mathrm{C}$. The protein concentration of the resulting supernatant was determined using a bicinchoninic acid protein assay kit (Beyotime Institute of Biotechnology). Proteins $(50 \mu \mathrm{g})$ were separated by $12 \%$ SDS-PAGE electrophoresis (Beyotime Institute of Biotechnology) and subsequently transferred to polyvinylidene difluoride membranes. Membranes were blocked with 5\% non-fat dry milk in Tris-buffered saline/Tween-20 $(0.05 \%, \mathrm{v} / \mathrm{v})$ for $2 \mathrm{~h}$ at room temperature and incubated overnight at $4^{\circ} \mathrm{C}$ with the rabbit TRAIL, GSK-3 $\beta$, $\beta$-catenin, Bcl-xL, cIAP2 and GAPDH primary antibodies. The blots were washed and incubated with a horseradish peroxidase-conjugated secondary antibody (Agilent Technologies, Santa Clara, CA, USA) and developed with the chemiluminescent substrate ECL Plus (Pierce Biotechnology, Inc., Rockford, IL, USA). An autoradiograph was obtained, and protein levels were measured using a Fluor-S scanner for grayscale determination and Quantity One software for analysis (Bio-Rad Laboratories, Inc., Hercules, CA, USA).

Quantification by reverse transcription quantitative-polymerase chain reaction ( $R T-q P C R)$. Transfected and untreated cells were collected and washed with PBS. Total RNA was extracted from the cells using TRIzol ${ }^{\circledR}$ reagent (Invitrogen Life Technologies) and complementary (c)DNA (1 $\mu$ l) was generated using a PrimeScript ${ }^{\circledR}$ RT reagent kit (Takara, 
A

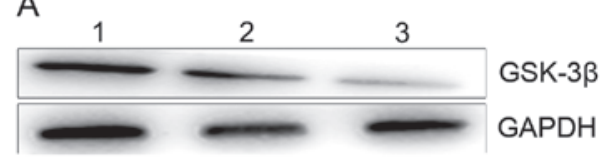

C

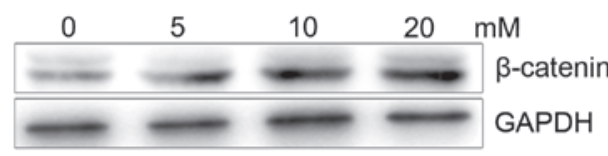

B

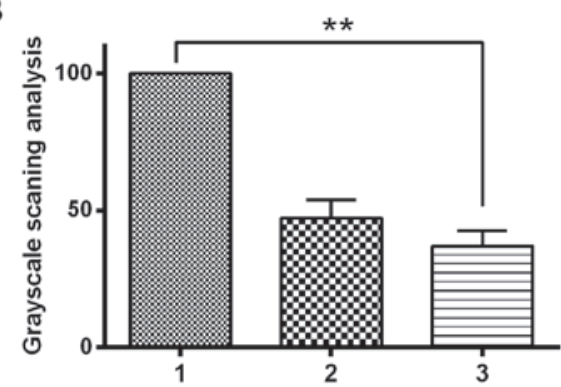

D

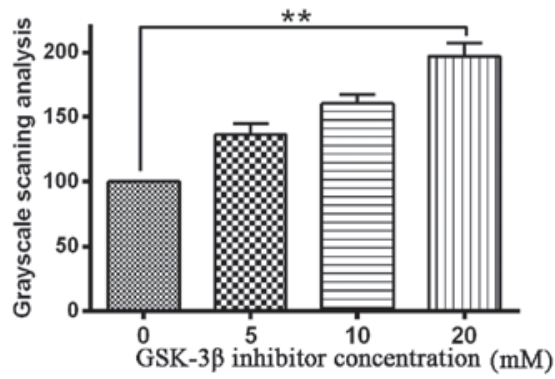

Figure 3. Effect of GSK-3 $\beta$ knockdown by GSK-3 $\beta$ inhibitor in HepG2 hepatocellular carcinoma cells. (A) Western blot analysis of GSK-3 $\beta$ protein expression levels. An anti-GAPDH antibody was used to confirm equal protein loading (bottom panel). (B) Grayscale scanning analysis revealing that GSK-3 $\beta$

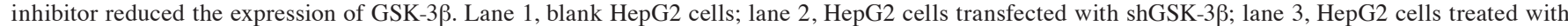
GSK-3 $\beta$ inhibitor (SB216763). (C) Western blot analysis of $\beta$-catenin expression levels in HepG2 cells treated with the indicated concentrations of GSK-3 $\beta$ inhibitor. (D) Grayscale scanning analysis revealing that the higher the concentration of GSK-3 $\beta$ inhibitor, the higher the expression of $\beta$-catenin. ${ }^{* *} \mathrm{P}<0.05$. GSK-3 $\beta$, glycogen synthase kinase $3 \beta$.

Chiga, Japan) at a total volume of $20 \mu 1$, according to the manufacturer's instructions. This cDNA was then used in each amplification reaction. The primers used were as follows: Forward, 5'-CTGGGCTACACTGAGCACC-3' and reverse, 5'-AAGTGGTCGTTGAGGGCAATG-3' for GSK-3ß; and forward, 5'-AGACGCTCCCTGTGATTTATGT-3' and reverse, 5'-CCGATGGCAGATTCCAAAGG-3' for GAPDH. Reactions were performed using SYBR ${ }^{\circledR}$ Premix Ex Taq ${ }^{\mathrm{TM}}$ (Takara) under the following PCR conditions: $95^{\circ} \mathrm{C}$ for $30 \mathrm{sec}$, followed by 40 cycles of $95^{\circ} \mathrm{C}$ for $5 \mathrm{sec}$ and $60^{\circ} \mathrm{C}$ for $30 \mathrm{sec}$. Amplification specificity was also confirmed by generating a melting curve for each sample. The expression of proteins was assessed by normalization of the cycle threshold $(\mathrm{Ct})$ of these genes to that of the housekeeping gene GAPDH. A Ct value was obtained from each amplification curve using the software provided by the manufacturer (Roche Diagnostics $\mathrm{GmbH}$, Mannheim, Germany).

Statistical analysis. Student's t-test and one-way analysis of variance were performed for continuous variables. The $\chi^{2}$ or Fisher's exact test were used for categorical variables. Error bars in all cases represent the standard error of the mean. All statistical analyses were performed using SAS 9.0 software (SAS Institute, Inc., Cary, NC, USA) and, using two-sided tests, $\mathrm{P}<0.05$ indicated a statistically significant difference.

\section{Results}

GSK-3 $\beta$ downregulation inhibits the proliferation of HCC cells. Previous studies have reported that direct downregulation of GSK-3 protein expression inhibits glioma cell growth (19).
GSK-3 $\beta$ is one of the two GSK-3 isoforms and its expression was determined in five cell lines using western blot analysis in the present study (Fig. 1). To examine the role of GSK-3 $\beta$ in HCC cells, the effect of downregulation of GSK-3 $\beta$ protein expression on $\mathrm{HCC}$ cell growth was investigated. HepG2 cells were divided into three groups: Blank HepG2 cells, shGSK-3 $\beta$-treated cells and shRNA-treated control cells. Western blotting and RT-qPCR identified that GSK-3 $\beta$ protein and mRNA expression levels, respectively, were significantly downregulated by shGSK-3 $\beta$ in HepG 2 cells $(\mathrm{P}<0.05$; Fig. 2A-C). Furthermore, shRNA-mediated downregulation of GSK-3 $\beta$ resulted in growth inhibition, as revealed by the MTT assay. Compared with the shRNA control cells, there was a significant growth delay in shGSK-3 $\beta$-treated cells by $72 \mathrm{~h}(\mathrm{P}<0.05$; Fig. 2D). These results demonstrate that GSK-3 $\beta$ downregulation inhibited the proliferation of HCC cells.

GSK-3 $\beta$ inhibitor sensitizes HCC cells to TRAIL-induced apoptosis. The protein expression level of GSK-3 $\beta$ was detected by western blotting following treatment of HepG2 cells with SB216763 (a specific of inhibitor of GSK- $3 \beta$ ) and GSK-3 $\beta$ shRNA. As GSK-3 phosphorylates $\beta$-catenin for proteasomal degradation, the level of phosphorylated $\beta$-catenin reflects the activity of GSK-3. It follows that pretreatment with a GSK-3 inhibitor completely inhibits phosphorylation of $\beta$-catenin, thus, increasing the levels of $\beta$-catenin (20). To determine the effects of GSK-3 $\beta$ inhibitor on GSK-3 $\beta$ activity in HepG 2 cells, western blot was used to analyze the protein expression levels of $\beta$-catenin. Western blotting confirmed that the GSK-3 $\beta$ inhibitor significantly inhibited GSK-3 $\beta$ expression compared with the blank control 
A

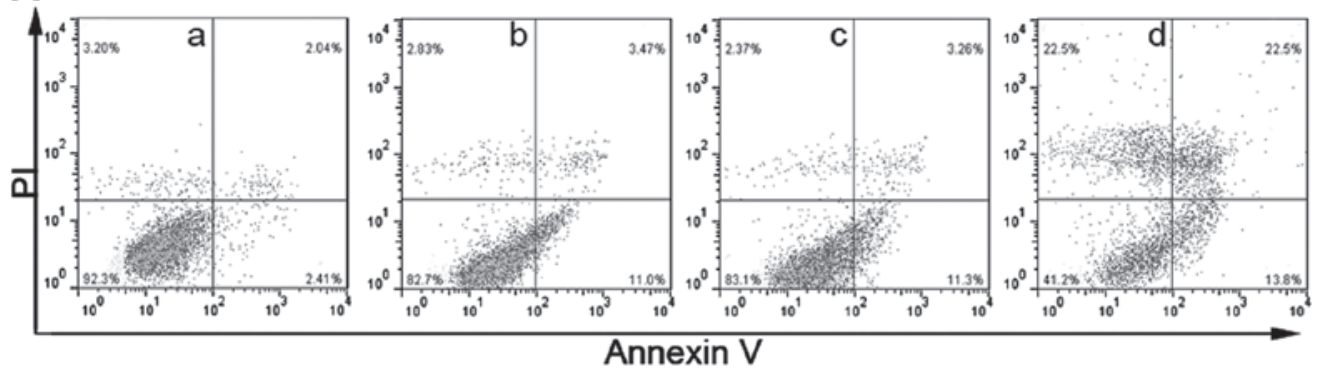

B

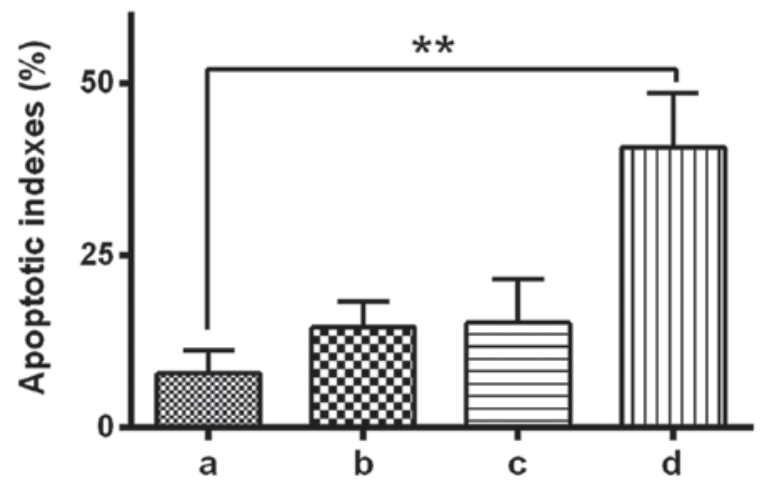

Figure 4. Glycogen synthase kinase $3 \beta$ (GSK-3 $\beta$ ) inhibition enhances tumor necrosis factor-related apoptosis-inducing ligand (TRAIL)-induced apoptosis in HuH-7 hepatocellular carcinoma cells. (A) Detection of the apoptosis of HuH-7 cells by flow cytometric assay. HuH-7 cells were treated with GSK-3 $\beta$ inhibitor and Ad5.TRAIL alone or in combination at the indicated doses for $48 \mathrm{~h}$. The cells were then harvested and stained with Annexin V-phycoerythrin or propidium iodide to distinguish between apoptotic and dead cells. Finally, the stained cells were analyzed by flow cytometry (a, control; b, GSK-3 $\beta$ inhibitor; c, Ad5. TRAIL; d, GSK-3 $\beta$ inhibitor plus Ad5.TRAIL). The total apoptotic cells were considered as the percentage of quadrant (Q)IV (early apoptosis) cells plus the percentage of QII (late apoptosis) cells. (B) Apoptosis index represented by the mean percentage of Annexin V-positive cells. Each data point represents the mean \pm standard deviation (bars). GSK-3 $\beta$ inhibitor and Ad5.TRAIL treatment significantly induced the apoptosis of HuH-7 cells. ${ }^{* *} \mathrm{P}<0.01$.

A

1

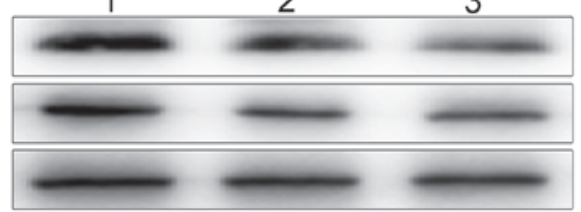

B

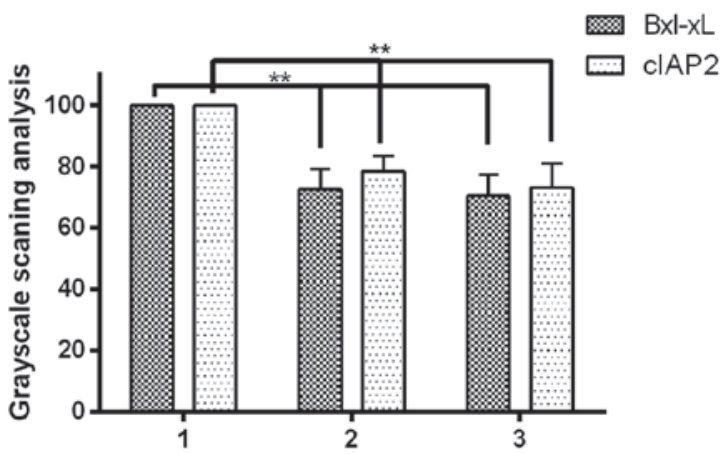

Figure 5. Effect of glycogen synthase kinase $3 \beta$ (GSK-3 $\beta$ ) inhibition on Bcl-xL and cIAP2 expression. HepG 2 cells were divided into three groups: Lane 1, blank HepG2 cells; lane 2, HepG2 cells transfected with GSK-3 $\beta$ short hairpin RNA; lane 3, HepG2 cells treated with GSK-3 $\beta$ inhibitor. (A) Western blot analysis of Bcl-xL and cIAP2 protein expression levels. (B) Grayscale scanning analysis revealing that GSK-3 $\beta$ inhibition reduced the expression of Bcl-xL and cIAP2. ${ }^{* *} \mathrm{P}<0.05$. cIAP2, cellular inhibitor of apoptosis protein 2; Bcl-xL, B-cell lymphoma-extra large.

$(\mathrm{P}<0.05$; Fig. $3 \mathrm{~A}$ and $\mathrm{B})$. The results also demonstrated that GSK-3 $\beta$ inhibition significantly enhanced $\beta$-catenin expression $(\mathrm{P}<0.05)$, indirectly indicating effective inhibition of GSK-3 $\beta$ activity in HepG 2 cells. This enhancement of $\beta$-catenin expression occurred in a dose-dependent manner (Fig. 3C and D). Our previous study verified that infection of non-small cell lung cancer cells with Ad5.TRAIL resulted in significant cytotoxicity (21). To investigate the potential role of GSK-3 $\beta$ in TRAIL-induced apoptosis, the effect of a GSK-3 $\beta$ inhibitor on TRAIL-induced cytotoxicity was analyzed using fluorescence-activated cell sorting. Due to the high expression of GSK-3 $\beta$ compared with the other HCC cells investigated, HuH-7 cells were used for this experiment. HuH-7 cells were treated with GSK-3 $\beta$ inhibitor and Ad5.TRAIL alone or in combination. The results indicated that combined treatment with GSK-3 $\beta$ inhibitor and Ad5.TRAIL led to a significant increase in apoptosis compared with untreated cells $(\mathrm{P}<0.01)$. By contrast, GSK-3 $\beta$ inhibitor/Ad5.TRAIL combined treatment resulted in a significant induction of cell apoptosis $(\mathrm{P}<0.05)$. Thus, the present study demonstrated that TRAIL-induced apoptosis is enhanced following GSK-3 $\beta$ inhibition in HuH-7 cells (Fig. 4A and B). 

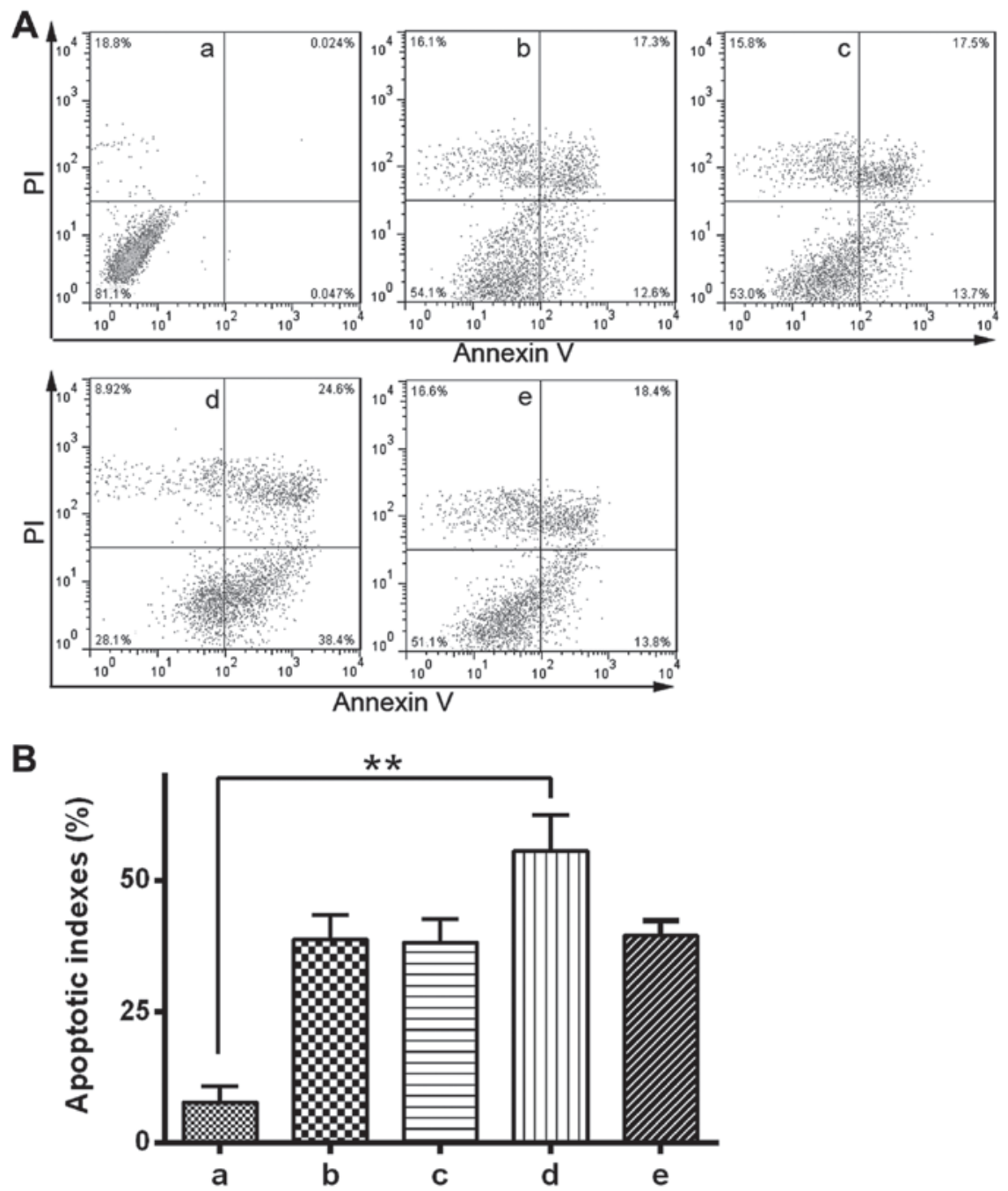

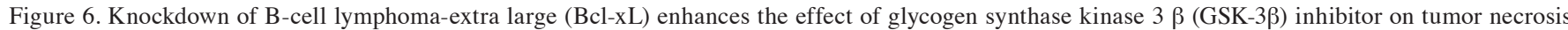
factor-related apoptosis-inducing ligand (TRAIL)-induced apoptosis. HuH-7 cells were divided into five groups of cells treated with: a, Blank control; b, Ad5.TRAIL and short hairpin (sh)Bcl-xL; c, Ad5.TRAIL and sh cellular inhibitor of apoptosis protein 2 (cIAP2); d, Ad5.TRAIL, shBcl-xL and GSK-3 $\beta$ inhibitor; and e, Ad5.TRAIL, shcIAP2 and GSK-3 $\beta$ inhibitor. (A) Detection of apoptotic HuH-7 cells by flow cytometric assay. (B) Apoptosis index demonstrating that the apoptosis of cells treated with Ad5.TRAIL, shBcl-xL and GSK-3 $\beta$ inhibitor were significantly enhanced. ${ }^{* *} \mathrm{P}<0.05$. PI, propidium iodide.

GSK-3 $\beta$ modulates a specific set of $N F-\kappa B$ target genes. $\mathrm{NF}-\mathrm{KB}$ is a critical factor in protecting hepatocytes from apoptosis (22). TRAIL has been reported to activate the transcription factor NF- $\mathrm{KB}$, which transactivates genes encoding the key anti-apoptotic proteins Bcl-xL and IAPs, both of which have been implicated in TRAIL resistance $(10,11)$. The current findings demonstrated that GSK-3 $\beta$ inhibitor sensitizes HCC cells to TRAIL-induced apoptosis, suggesting that GSK-3 $\beta$ may be involved in the regulation of NF- $\mathrm{BB}$ activation. To prove this hypothesis, the effect of GSK- $3 \beta$ on NF- $\mathrm{KB}$ target genes, which encode the key anti-apoptotic proteins Bcl-xL and cIAP2, was evaluated. Western blotting demonstrated that downregulation of GSK- $3 \beta$ by shGSK-3 $\beta$ or GSK- $3 \beta$ inhibitor in HepG2 HCC cells significantly decreased the expression of $\mathrm{Bcl}-\mathrm{xL}$ and cIAP2 ( $\mathrm{P}<0.05$; Fig. 5A and $\mathrm{B})$. The results indicated that GSK-3 $\beta$ has the potential to regulate NF- $\mathrm{kB}$ target genes involved in cell survival.

Knockdown of Bcl-xL enhances the effect of GSK-3 $\beta$ inhibitor on TRAIL-induced apoptosis. A recent study revealed that Bcl-xL downregulation contributes to GSK-3 $\beta$ inhibitor-induced sensitization to TRAIL in pancreatic ductal adenocarcinoma cells (11). To evaluate the role of Bcl-xL and cIAP2 on TRAIL-induced apoptosis in HCC cells, shRNA was used to generate $\mathrm{HuH}-7$ cells with stable knockdown of each gene. Subsequently, the response of shBcl-xL- and shcIAP2-treated HuH-7 cells to TRAIL-induced apoptosis was determined. The results indicated that $\mathrm{Bcl}-\mathrm{xL}$ and cIAP2 knockdown each markedly enhanced TRAIL-induced apoptosis (Fig. 6). To further examine whether Bcl-xL actively participates in GSK-3 $\beta$ inhibitor-mediated TRAIL sensitization, apoptosis was measured following treatment with GSK-3 $\beta$ inhibitor (Fig. 6). The results indicated that knockdown of Bcl-xL significantly enhances the effect of GSK- $3 \beta$ inhibitor on TRAIL-induced apoptosis $(\mathrm{P}<0.05$; Fig. 6).

\section{Discussion}

GSK-3 $\beta$ modulates cell survival and apoptosis through multiple intracellular signaling pathways $(23,24)$. In the present study, 
downregulation of GSK-3 $\beta$ resulted in growth inhibition in HCC cells, which is consistent with previous reports (12). The aim of the current study was to investigate whether inhibition of GSK-3 $\beta$ could induce TRAIL-reduced apoptosis in HCC cells. The results herein demonstrated that chemical inhibition or genetic silencing of GSK-3 $\beta$ sensitizes HCC cells to TRAIL-induced apoptosis. Furthermore, it was found that GSK-3 $\beta$ inhibitor-induced TRAIL sensitization depends upon the activity of $N F-\kappa B$. These results provide a novel mechanism for GSK-3 $\beta$ modulation of TRAIL sensitivity in HCC cells.

TRAIL resistance has been observed in a variety of cell types $(25,26)$ and is caused by the differential expression of TRAIL receptors, as well as by intracellular molecules, such as Akt and Bcl-2, which modulate the downstream effect of TRAIL signaling $(27,28)$. GSK-3 $\beta$ has been implicated in apoptosis under a variety conditions, including DNA damage, endoplasmic reticulum stress and hypoxia $(13,29,30)$. GSK-3 $\beta$ inhibitors are used in the treatment of Alzheimer's disease, diabetes and inflammatory disorders $(31,32)$. In an oncology setting, previous studies have shown that GSK-3 $\beta$ inhibitors sensitize prostate cancer cells to TRAIL-induced apoptosis (33). The present study demonstrates the mechanism by which GSK-3 $\beta$ inhibits TRAIL-induced apoptosis of sensitized HCC cells. The rationale was based on the premise that GSK-3 $\beta$ inhibition in HCC cells downregulates the expression of key anti-apoptotic proteins that mediate TRAIL resistance. For example, previous studies have demonstrated that TRAIL stimulates $N F-\kappa B$ activation, while inhibition of $N F-\kappa B$ sensitizes cells to TRAIL-mediated apoptosis in various cell lines $(10,34)$. Since the first report that genetic ablation of the murine GSK-3 $\beta$ gene perturbs NF- $\kappa \mathrm{B}$ activation (35), the role of GSK-3 $\beta$ in NF- $\kappa \mathrm{B}$ signaling has been investigated in a number of cell types. However, conflicting results have been reported regarding the role of GSK-3 $\beta$ in promoting $\mathrm{NF}-\kappa \mathrm{B}$ activity, ranging from major defects in $\mathrm{TNF} \alpha$-induced inhibitor of $\kappa \mathrm{B} \alpha$ $(\mathrm{I} \kappa \mathrm{B} \alpha)$ phosphorylation to minor effects on cytosolic signaling pathways and p65 nuclear translocation $(16,36)$. In addition, Bcl-2 was reported to inhibit TRAIL-mediated cell death (27). IAPs constitute a protein family that regulates programmed cell death (37), and a recent study demonstrated that GSK-3 $\beta$ induces Bcl-xL and cIAP2 expression in pancreatic cancer cells (11). Consistent with this, the results of the present study indicate that GSK-3 $\beta$ may also regulate the expression of the BCL2L1 and BIRC3 genes, which encode anti-apoptosis proteins $\mathrm{Bcl}-\mathrm{xL}$ and cIAP2 in HCC cells, respectively, and are known downstream targets of $\mathrm{NF}-\kappa \mathrm{B}$. Notably, suppression of Bcl-xL and cIAP2 sensitized HCC cells to TRAIL-induced apoptosis. Furthermore, knockdown of Bcl-xL signaling enhanced the effect of GSK-3 $\beta$ inhibitor on TRAIL-induced apoptosis. These results are consistent with a previous study that demonstrated a role for Bcl-xL in mediating TRAIL resistance (25). A limitation of the current study is that only two NF- $\kappa \mathrm{B}$ target genes were examined. Thus, it is unknown whether the NF- $\mathrm{B}$ inhibitor $\mathrm{I} \kappa \mathrm{B} \alpha$ and a number of other $\mathrm{NF}-\kappa \mathrm{B}$ target genes are not involved in mediating TRAIL resistance. The detailed mechanisms underlying GSK- $3 \beta$ regulation of the $\mathrm{NF}-\kappa \mathrm{B}$ signaling pathway have yet to be fully elucidated.

GSK-3 $\beta$ inhibition can overcome TRAIL resistance through the extrinsic apoptotic pathway by promoting the initial step of death-inducing signaling complex formation, leading to caspase- 8 and caspase- 3 activation in breast cancer cells (38). The results of the current study revealed that GSK-3 $\beta$ can regulate the TRAIL-dependent inhibition of apoptosis at the mRNA and protein levels in HCC cells. Thus, the $\mathrm{NF}-\kappa \mathrm{B}$ signaling pathways are promising targets for cancer therapy (39). The canonical and noncanonical pathways can be inhibited to modulate $\mathrm{NF}-\kappa \mathrm{B}$ activity, and possibly treat various types of disease. The present study indicates that GSK-3 $\beta$ inhibitor enhances TRAIL-induced apoptosis in HCC cells. Furthermore, GSK-3 $\beta$ contributes to TRAIL resistance by modulating the expression of a set of specific anti-apoptotic $\mathrm{NF}-\kappa \mathrm{B}$ target genes. The subcellular location (nucleus or cytoplasm) in which GSK-3 $\beta$ regulates $N F-\kappa B$ function was not explored in the present study. Future studies may determine whether GSK-3 $\beta$ contributes to the expression of Bcl-xL and cIAP2 via nucleic or cytoplasmic targeting and, thus, indicate whether the signaling cascades differ.

In conclusion, the present study demonstrates that GSK-3 $\beta$ suppression sensitizes HCC cells to TRAIL-induced apoptosis, and is dependent on the $\mathrm{NF}-\kappa \mathrm{B}$ signaling pathway. An understanding of the role of GSK-3 $\beta$ in TRAIL resistance may offer improved therapeutic strategies for patients with HCC.

\section{Acknowledgements}

The present study was supported by a grant from the National Natural Science Foundation of China (grant no. 81372632).

\section{References}

1. El-Serag, HB and Rudolph KL: Hepatocellular carcinoma: Epidemiology and molecular carcinogenesis. Gastroenterology 132: 2557-2576, 2007.

2. Llovet JM, Burroughs A and Bruix J: Hepatocellular carcinoma. Lancet 362: 1907-1917, 2003.

3. Cheng CF, Lu IH, Tseng HW, Sun CY, Lin LT, Kuo ZK, Pan IH and Ko CH: Antitumor Effect of Periplocin in TRAIL-Resistant Human Hepatocellular Carcinoma Cells through Downregulation of IAPs. Evid Based Complement Alternat Med 2013: Article ID 958025, 2013

4. Chiao PJ, Na R, Niu J, Sclabas GM, Dong Q and Curley SA: Role of Rel/NF-kappaB transcription factors in apoptosis of human hepatocellular carcinoma cells. Cancer 95: 1696-1705, 2002.

5. Wiley SR, Schooley K, Smolak PJ, et al: Identification and characterization of a new member of the TNF family that induces apoptosis. Immunity 3: 673-682, 1995.

6. Wajant H, Pfizenmaier K and Scheurich P: TNF-related apoptosis inducing ligand (TRAIL) and its receptors in tumor surveillance and cancer therapy. Apoptosis 7: 449-459, 2002.

7. Srivastava RK: TRAIL/Apo-2L: Mechanisms and clinical applications in cancer. Neoplasia 3: 535-546, 2001.

8. Spierings DC, de Vries EG, Vellenga E, et al: Tissue distribution of the death ligand TRAIL and its receptors. J Histochem Cytochem 52: 821-831, 2004.

9. Smyth MJ, Takeda K, Hayakawa Y, et al: Nature's TRAIL - on a path to cancer immunotherapy. Immunity 18: 1-6, 2003.

10. Omar HA, Arafa SA, Maghrabi IA and Weng JR: Sensitization of hepatocellular carcinoma cells to Apo2L/TRAIL by a novel Akt/NF- $\kappa \mathrm{B}$ signalling inhibitor. Basic Clin Pharmacol Toxicol 114: 464-471, 2014.

11. Zhang JS, Herreros-Villanueva M, Koenig A, et al: Differential activity of GSK-3 isoforms regulates NF- $\kappa \mathrm{B}$ and TRAIL- or TNFa induced apoptosis in pancreatic cancer cells. Cell Death Dis 5: e1142, 2014.

12. Forde JE and Dale TC: Glycogen synthase kinase 3: A key regulator of cellular fate. Cell Mol Life Sci 64: 1930-1944, 2007. 
13. Song L, De Sarno P and Jope RS: Central role of glycogen synthase kinase-3beta in endoplasmic reticulum stress-induced caspase-3 activation. J Biol Chem 277: 44701-44708, 2002.

14. Pak C and Miyamoto S: A new alpha in line between KRAS and NF- $\mathrm{kB}$ activation? Cancer Discov 3: 613-615, 2013.

15. Yao HB, Shaw PC, Wong CC and Wan DCC: Expression of glycogen synthase kinase-3 isoforms in mouse tissuesand their transcription in the brain. J Chem Neuroanat 23: 291-297, 2002.

16. Schwabe RF and Brenner DA: Role of glycogen synthase kinase-3 in TNF-alpha-induced NF-kappaB activation and apoptosis in hepatocytes. Am J Physiol Gastrointest Liver Physiol 283: G204-G211, 2002.

17. Coghlan MP, Culbert AA, Cross DA, et al: Selective small molecule inhibitors of glycogen synthase kinase-3 modulate glycogen metabolism and gene transcription. Chem Biol 7: 793-803, 2000.

18. Liu J, Jiang G, Liu S, et al: Lentivirus-delivered short hairpin RNA targeting SNAIL inhibits HepG2 cell growth. Oncol Rep 30: 1483-1487, 2013.

19. Kotliarova S, Pastorino S, Kovell LC, Kotliarov Y, Song H, Zhang W, Bailey R, Maric D, Zenklusen JC, Lee J, et al: Glycogen synthase kinase-3 inhibition induces glioma cell death through c-MYC, nuclear factor-kappaB, and glucose regulation. Cancer Res 68: 6643-6651, 2008.

20. Kim SJ, Lim JY, Lee JN, Choe SK, Kim YI, Song SR, Cho M, So HS and Park R: Activation of $\beta$-catenin by inhibitors of glycogen synthase kinase-3 ameliorates cisplatin-induced cytotoxicity and pro-inflammatory cytokine expression in HEI-OC1 cells. Toxicology 320: 74-82, 2014.

21. Zhang H, Sui A, Wang Z, Liu S and Yao R: Adenovirus-mediated TRAIL expression and downregulation of Bcl-2 expression suppresses non-small cell lung cancer growth in vitro and in vivo. Int J Mol Med 30: 358-364, 2012.

22. Kim HS, Loughran PA, Rao J, Billiar TR and Zuckerbraun BS Carbon monoxide activates NF-kappaB via ROS generation and Akt pathways to protect against cell death of hepatocytes. Am J Physiol Gastrointest Liver Physiol 295: G146-G152, 2008.

23. Jope RS and Johnson GV: The glamour and gloom of glycogen synthase kinase-3. Trends Biochem Sci 29: 95-102, 2004.

24. Beurel E and Jope RS: The paradoxical pro- and anti-apoptotic actions of GSK3 in the intrinsic and extrinsic apoptosis signaling pathways. Prog Neurobiol 79: 173-189, 2006.

25. Chen KF, Yeh PY, Hsu C, Hsu CH, Lu YS, Hsieh HP, Chen PJ and Cheng AL: Bortezomib overcomes tumor necrosis factor-related apoptosis-inducing ligand resistance in hepatocellular carcinoma cells in part through the inhibition of the phosphatidylinositol 3-kinase/Akt pathway. J Biol Chem 284: 11121-11133, 2009.

26. Newsom-Davis T, Prieske $S$ and Walczak H: Is TRAIL the holy grail of cancer therapy? Apoptosis 14: 607-623, 2009.
27. Munshi A, Pappas G, Honda T, McDonnell TJ, Younes A, Li Y and Meyn RE: TRAIL (APO-2L) induces apoptosis in human prostate cancer cells that is inhibitable by Bcl-2. Oncogene 20: 3757-3765, 2001

28. Chen X, Thakkar H, Tyan F, Gim S, Robinson H, Lee C, Pandey SK, Nwokorie C, Onwudiwe N and Srivastava RK: Constitutively active Akt is an important regulator of TRAIL sensitivity in prostate cancer. Oncogene 20: 6073-6083, 2001.

29. Loberg RD, Vesely E and Brosius FC III: Enhanced glycogen synthase kinase-3beta activity mediates hypoxia-induced apoptosis of vascular smooth muscle cells and is prevented by glucose transport and metabolism. J Biol Chem 277: 41667-41673, 2002

30. Watcharasit P, Bijur GN, Zmijewski JW, Song L, Zmijewska A, Chen X, Johnson GV and Jope RS: Direct, activating interaction between glycogen synthase kinase-3beta and p53 after DNA damage. Proc Natl Acad Sci USA 99: 7951-7955, 2002.

31. Klamer G, Song E, Ko KH, O'Brien TA and Dolnikov A: Using small molecule GSK3 $\beta$ inhibitors to treat inflammation. Curr Med Chem 17: 2873-2881, 2010.

32. Medina M and Avila J: Glycogen synthase kinase-3 (GSK-3) inhibitors for the treatment of Alzheimer's disease. Curr Pharm Des 16: 2790-2798, 2010.

33. Liao X, Zhang L, Thrasher JB, Du J and Li B: Glycogen synthase kinase- $3 \beta$ suppression eliminates tumor necrosis factor-related apoptosis-inducing ligand resistance in prostate cancer. Mol Cancer Ther 2: 1215-1222, 2003.

34. Huerta-Yepez S, Vega M, Jazirehi A, Garban H, Hongo F, Cheng $G$ and Bonavida B: Nitric oxide sensitizes prostate carcinoma cell lines to TRAIL-mediated apoptosis via inactivation of NF-kappa B and inhibition of Bcl-xl expression. Oncogene 23: 4993-5003, 2004.

35. Hoeflich KP: Requirement for glycogen synthase kinase-3 $\beta$ cell survival and NF- $\kappa \mathrm{B}$ activation. Nature 406: 86-90, 2001

36. Wilson W III and Baldwin AS: Maintenance of constitutive IkappaB kinase activity by glycogen synthase kinase-3alpha/beta in pancreatic cancer. Cancer Res 68: 8156-8163, 2008.

37. Deveraux QL and Reed JC: IAP family proteins - suppressors of apoptosis. Genes Dev 13: 239-252, 1999.

38. Sun M, Zhou T, Jonasch E and Jope RS: DDX3 regulates DNA damage-induced apoptosis and p53 stabilization. Biochim Biophys Acta 1833: 1489-1497, 2013.

39. Carbone C and Melisi D: NF-kB as a target for pancreatic cancer therapy. Expert Opin Ther Targets 16: 1-10, 2012. 